\title{
THE COMPARISON OF ORGANISATIONAL PAY STRUCTURES AS A SALARY SURVEY TECHNIQUE IN PROVIDING A UNIFIED NON-RACIAL MARKET WAGE CURVE
}

\author{
R.J. SNELGAR * \\ DEPARTMENT OF INDUSTRIAL AND ORGANISATIONAL PSYCHOLOGY \\ UNIVERSITY OF PORT ELIZABETH
}

\section{OPSOMMING}

\begin{abstract}
Die ontwikkeling en instandhouding van 'n regverdige en uniforme besoldigingstruktuur word gekompliseer deur die bestaan van 'n "loongaping”. Die keuse van 'n posevalueringplan wat nie bestaande diskriminasie laat voortbestaan nie, en wat self ook nie diskriminerend is nie, is 'n onderwerp waaroor heelwat debat gevoer word. Die resultate van hierdie studie dui aan dat dit moontlik is om 'n tegniek van salarisopname te gebruik wat nie op subjektiewe tegnieke soos posevaluering staat maak nie. 'n Vergelyking wat die totale organisasie se besoldigingstruktuur in ag neem eerder as die werklike salarisse, voorsien 'n basis vir 'n uniforme mark-salariskurwe wat nie rasseverskille reflekteer nie en waarvolgens die interne besoldigingsisteem mededingend gestruktureer kan word.
\end{abstract}

The primary purpose of job evaluation is to provide an objective grading of jobs in terms of relative worth such that an equitable and consistent pay structure may be established. The grading and grouping of jobs as determined by a system of job evaluation should replicate in money terms what is perceived to be fair and equitable by both management and employees, as a function of criteria such as the market supply and demand situation, legislation, collective bargaining pairer, and the value system of the society at a particular point in time.

The issue of an objective system of job evaluation has long been the major stumbling block to the selection by organisations of a particular plan suitable to needs, an issue which is further complicated by the large number of such systems in existence. This issue has become an area of major concern in South Africa, as the development of an equitable and uniform pay structure is somewhat clouded by the existence of the "wage gap", both between males and females, and more important, between Black and White.

\footnotetext{
* Requests for reprints should be sent to the author
} 
Thus, two basic areas of concern arise in the selection of an objective and reliable job evaluation plan within South Africa. The first is the perpetuation of discrimination already found in the marketplace. If a job evaluation plan purports to predict the market place, and the marketplace discriminates against certain positions, the job evaluation plan will perpetuate discrimination. Second, the most reliable and successful job evaluation plans use factor measurements of jobs (Paterson, 1972) and if these factors tend to discriminate between male and female dominated jobs, between male and female incumbents, or between Blacks and Whites, then the plan itself is discriminatory.

With these problems in mind, a number of plans have been proposed as suitable for the South African situation, with empirical evidence lending strong support for one particular system, namely the Paterson System, as a model system for examining aspects of the distribution of pay in an economy, highlighting differentially between different groups (Cogill and Pearson, 1978). The championing of this particular system or method for the South African situation is based on the finding that when current rates of basic pay for jobs evaluated by the method are plotted on a log scale "pay differentials between grades increase exponentially - the increase in average basic pay between each grade being more or less constant" (Livy, 1975). This finding allows organisations to structure their pay systems according to the market rates in such a way that the wage curve will represent what is perceived to be fair, and will thus avoid problems on the pay and industrial relation fronts, while at the same time allowing adequate study of the wage-gap over time (Cogill and Pearson, 1978) .

Using this logic to develop an equitable organisational pay structure a solution to the problem of the Black-White wage gap has been suggested by Orpen (1976). This solution involves distorting the wage curve in order to create a scale of wages which links the two separate White and Black wage curves. This results in differing progression rates at different levels of this unified wage curve. A return to a "unified non-racial wage curve" (Etheridge, 1973) could then be achieved by raising the employment level of Blacks in general, and raising wages of Black unskilled labourers at the bottom end of the job hierarchy above the subsistence level, irrespective of productivity. This is to be achieved over a period of five years (Orpen, 1976).

The success of such a proposal has been jeopardised to a large extent by the implications of having to provide these large increases, irrespective of productivity. This has 
been exemplified by problems stemming from organisations providing such increases subsequent to the mid-70's labour unrest (Orpen, 1974).

The application of the Paterson logic would thus seem to fail to provide a solution to the problem of an equitable and unified non-racial pay structure because the "intermediate" wage curve, as proposed by Orpen, requires differing progression rates at different levels of the wage curve. In other words, such a solution would require the use of techniques to link the Black and White wage curves, whereas the Paterson approach simply provides a straight line wage curve with a constant progression rate, or an exponential increase between grades. This logic is acceptable should the organisation wish to study the wage gap over-time, and structure its pay system according to actual wage rates within the market. This would imply the need for two separate pay structures in order to satisfy the basic logic of the system, and these structures imply a myriad of administrative problems.

This is precisely where the major problem area arises. The surveying of actual wage rates tends to introduce the subjective human element. Actual rates tend to reflect human factors such as experience, training, length of service, and this tends to distort what may be regarded as the "going rate" for the position in question. In surveying these actual salaries, then, perpetuation of discrimination already found in the marketplace cannot be avoided.

This study has thus been aimed at testing a technique which does not rely on the use of job evaluation as a method of obtaining "going rates", or current rates of basic pay from the market place. This technique has thus been developed to survey competitive market "going rates, while at the same time excluding disadvantages of job evaluation systems which may perpetuate discrimination. In short, this technique purports to reflect the competitive market wage curve in such a way that all rates are incorporated within the same wage curve. Organisations may thus adjust pay systems or structures according to market rates incorporated within one non-racial wage curve. Further, this technique does not rely on the surveying of actual rates, but reflects grade midpoints, or those rates representative of job ranges falling within respective job grades of pay structures. Finally, this technique does not rely on the logic of a uniform straight line exponential increase wage curve, but rather allows for differing progression rates at different levels of the curve. 


\section{METHOD}

In order to develop such a technique it was necessary to move away from individual position evaluations and comparisons. This would result in a movement away from surveying of actual salaries. Rather, a technique was developed which relied on comparisons of complete individual organisational wage curves which would ensure comparison of all relevant "going rates" in the form of grade midpoints applicable to respective pay structures of those organisations regarded as being competitive within the labour market.

To make comparisons on this basis, it was necessary to "standardise" pay structures of organisations supplying salary data for purposes of this study. Standardisation of pay structures was effected by establishing exact pay range comparisons, irrespective of midpoint values, according to techniques outlined in the wage and salary survey guide developed by Snelgar (1980). In this way each organisation's number of pay ranges were readjusted in order to ensure a uniform number of ranges for each organisation. This ensured individual range matching, or range-to-range comparisons. This in turn ensured comparisons of midpoints applicable to those matching ranges, these midpoints being regarded as the organisations' "going rates" for the group of positions falling within these particular pay ranges, or job grades. It thus becomes evident that midpoint comparisons allow, in effect, comparisons of groups of positions falling within these particular pay ranges represented by those midpoints. Comparisons of midpoints over total pay structure thus allow comparisons of going rates reflecting all positions within each organisation.

In order to test the feasibility and reliability of this technique in providing a uniform "non-racial" market wage curve on a consistent basis over time, as well as providing a basis allowing organisations to structure pay systems according to market rates, salary survey data was applied to this technique. This salary survey data was in the form of participating organisation base pay range midpoint values, based on a sample of 180 jobs, 30000 employees, and 60 organisations. The survey period spanned seven years, and involved three comprehensive surveys.

Current "going rates" in the form of base salary midpoints were plotted on a log scale on the vertical axis with job grade ratings on the horizontal axis, according to principles outlined above, and for each relevant survey period. All organisation pay structures were standardised according to a twenty-four grade structure for analysis purposes. The line of best fit, or market wage curves were then calculated according to each scatter gram. 
In order to provide a basis for comparison of results obtained from application of this technique with results obtained from application of job evaluation techniques, the same survey data obtained was applied to a South African developed job evaluation system. This system was originally developed between 1956 and 1962 (Biesheuvel, 1962), and has been thoroughly researched in separate studies (Cortis 1972; Biesheuvel, 1977), finally evolving into the system commonly known as the Peromnes system.

Results obtained from application of these techniques were compared graphically and statistically over the three survey periods.

\section{RESULTS AND DISCUSSION}

A comparison of the calculated wage curve values for each pay range (job grade) as applicable to each technique is presented for successive survey years in Table 1. A graphical comparison of these respective wage curves is provided in Figures 1, 2 and 3. Included in these illustrations are the respective Black and White wage curves revealing the extent of the wage-gap in each case. The differential in pay is represented by the vertical distance between corresponding rates as applicable to the upper dotted curve (White) versus the lower dotted curve (Black).

It may be noted that the unified non-racial wage curves, represented by the solid curve (job evaluation technique) and the dashed curve (pay structure technique), reveal differing progression rates over the entire market wage curve. In each case, however, there are three differing rates which correspond to different levels of the job hierarchy. Important is the fact that these different progression rates have corresponded with the same levels of the job hierarchy for each successive survey period.

The differing progression rates over the respective wage curves support the contention that it becomes necessary to distort the curve in order to provide a "non-racial unified curve", until such time that the wage-gap between Black and White wage rates has been significantly reduced. It is further important to note that the three basic progression rates reveal levels of the wage curve which are applicable to various job hierarchy divisions. The progression rates for job grades one to six basically represent the unskilled and semi-skilled levels of the job hierarchy; rates for grades six to eighteen represent the skilled and lower to mid-management levels; rates for grades eighteen to twenty-four represent mid-management to senior management levels. Furthermore, these groupings of grades have remained fairly constant over the seven survey years under consideration. 
TABLE 1

COMPARISON OF WAGE CURVE VALUES : MONTHLY BASE SALARY : RANDS

\begin{tabular}{|c|c|c|c|c|c|c|}
\hline & \multicolumn{2}{|c|}{1974} & \multicolumn{2}{|c|}{1977} & \multicolumn{2}{|c|}{1980} \\
\hline $\begin{array}{c}\text { Pay } \\
\text { Range } \\
\text { (Grade } \\
\text { No.) }\end{array}$ & $\begin{array}{l}\text { Pay } \\
\text { Structure } \\
\text { Technique }\end{array}$ & \begin{tabular}{l}
\multicolumn{1}{c}{ Job } \\
Evaluation \\
Technique
\end{tabular} & $\begin{array}{c}\text { Pay } \\
\text { Structure } \\
\text { Technique }\end{array}$ & \begin{tabular}{l}
\multicolumn{1}{c}{ Job } \\
Evaluation \\
Technique
\end{tabular} & $\begin{array}{c}\text { Pay } \\
\text { Structure } \\
\text { Technique }\end{array}$ & $\begin{array}{l}\text { Job } \\
\text { Evaluation } \\
\text { Technique }\end{array}$ \\
\hline $\begin{array}{r}1 \\
2 \\
3 \\
4 \\
5 \\
6 \\
7 \\
8 \\
9 \\
10 \\
11 \\
12 \\
13 \\
14 \\
15 \\
16 \\
17 \\
18 \\
19 \\
20 \\
21 \\
22 \\
23 \\
24\end{array}$ & $\begin{array}{r}145 \\
178 \\
218 \\
267 \\
327 \\
401 \\
436 \\
474 \\
516 \\
561 \\
610 \\
664 \\
722 \\
785 \\
854 \\
964 \\
1089 \\
1230 \\
1389 \\
1568 \\
1771 \\
2000 \\
2258 \\
2550\end{array}$ & $\begin{array}{r}145 \\
178 \\
218 \\
267 \\
327 \\
401 \\
436 \\
473 \\
514 \\
558 \\
606 \\
658 \\
715 \\
776 \\
843 \\
916 \\
1030 \\
1157 \\
1301 \\
1462 \\
1643 \\
1847 \\
2076 \\
2333\end{array}$ & $\begin{array}{r}188 \\
227 \\
274 \\
330 \\
398 \\
480 \\
530 \\
586 \\
647 \\
714 \\
789 \\
872 \\
963 \\
1063 \\
1174 \\
1297 \\
1432 \\
1583 \\
1778 \\
1997 \\
2244 \\
2520 \\
2832 \\
3183\end{array}$ & $\begin{array}{c}174 \\
213 \\
260 \\
318 \\
389 \\
475 \\
523 \\
576 \\
634 \\
698 \\
769 \\
846 \\
932 \\
1026 \\
1129 \\
1244 \\
1369 \\
1507 \\
1692 \\
1900 \\
2133 \\
2395 \\
2688 \\
3016\end{array}$ & $\begin{array}{r}227 \\
272 \\
327 \\
392 \\
471 \\
565 \\
626 \\
694 \\
769 \\
852 \\
944 \\
1046 \\
1159 \\
1284 \\
1423 \\
1577 \\
1747 \\
1956 \\
2190 \\
2452 \\
2756 \\
3075 \\
3443 \\
3855\end{array}$ & $\begin{array}{r}221 \\
265 \\
319 \\
383 \\
460 \\
553 \\
610 \\
673 \\
742 \\
818 \\
902 \\
995 \\
1097 \\
1210 \\
1335 \\
1472 \\
1625 \\
1813 \\
2025 \\
2261 \\
2525 \\
2620 \\
3148 \\
3516\end{array}$ \\
\hline
\end{tabular}




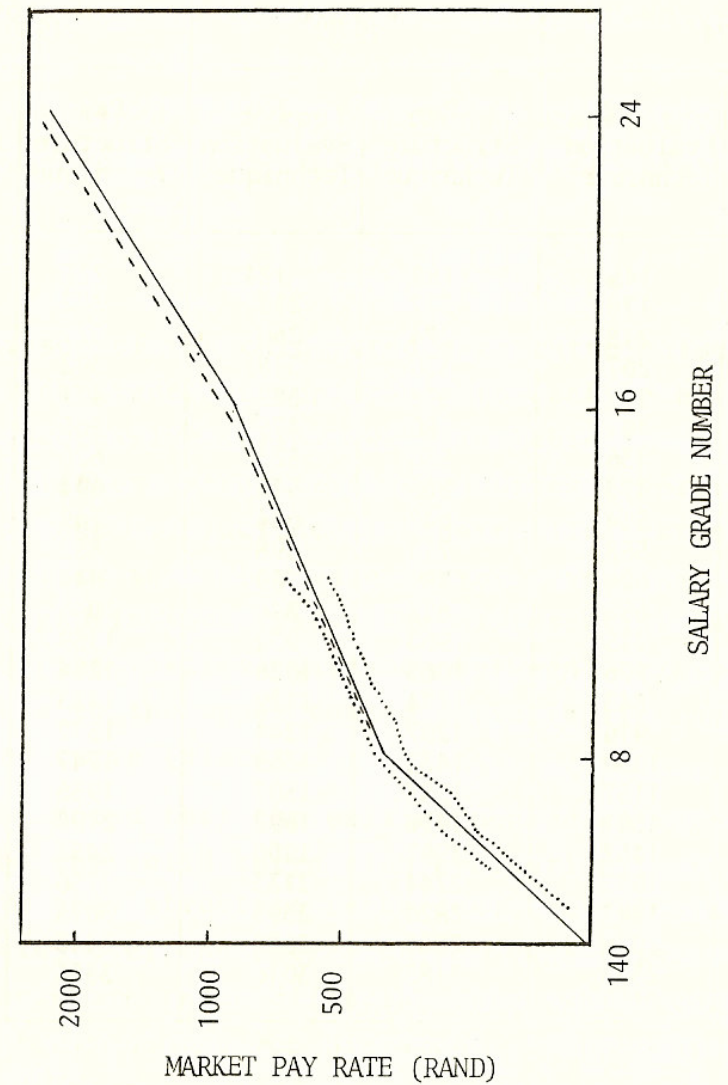

Figure 1 : Comparison of market wage curves : Job evaluation vs Pay structure techniques.

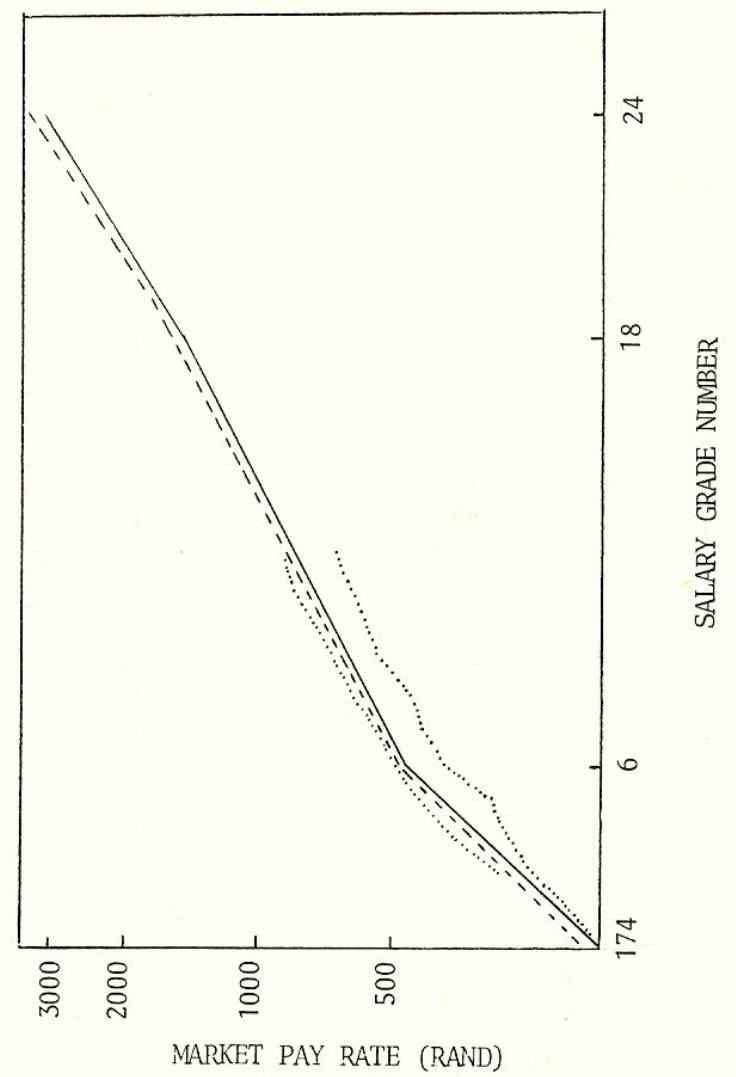

Figure 2 : Comparison of market wage curves : Job evaluation vs Pay structure techniques. 


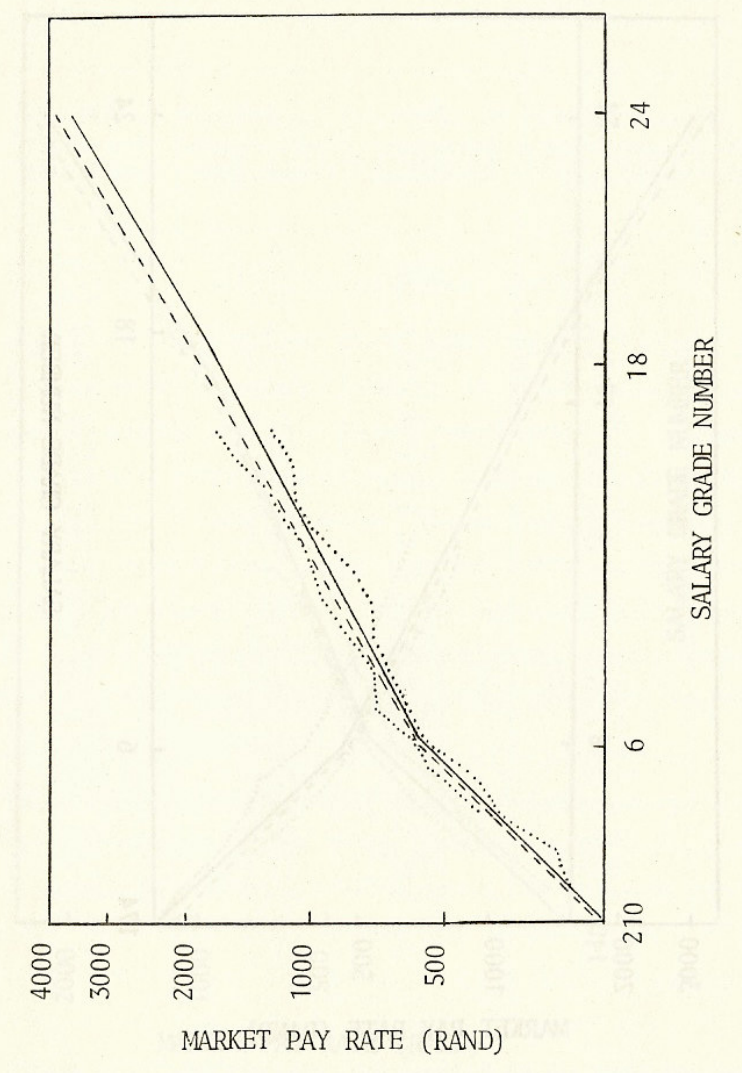

Figure 3 : Comparison of market wage curves : Job evaluation vs Pay structure techniques.

TABLE 2

COMPARISON OF WAGE CURVE PROGRESSION RATES

\begin{tabular}{|r|c|c|c|c|c|}
\hline \multicolumn{9}{|c|}{1974} & \multicolumn{2}{c|}{ SURVEY } \\
\hline \multicolumn{2}{|c|}{ Pay structure technique } & \multicolumn{3}{c|}{ Job evaluation technique } \\
\hline Grade No. & $\begin{array}{c}\text { Rand } \\
\text { Cut-off value }\end{array}$ & Rate & Grade No. & $\begin{array}{c}\text { Rand } \\
\text { Cut-off value }\end{array}$ & Rate \\
\hline $1-6$ & $145-401$ & 1,2256 & $1-6$ & $145-401$ & 1,2256 \\
$6-15$ & $401-854$ & 1,0876 & $6-16$ & $401-916$ & 1,0861 \\
$15-24$ & $854-2550$ & 1,1292 & $16-24$ & $916-2333$ & 1,12396 \\
\hline
\end{tabular}

1977 SURVEY

\begin{tabular}{|r|r|c|r|r|c|}
\hline \multicolumn{3}{|c|}{ Pay structure technique } & \multicolumn{3}{c|}{ Job evaluation technique } \\
\hline Grade No. & $\begin{array}{c}\text { Rand } \\
\text { Cut-off value }\end{array}$ & Rate & Grade No. & $\begin{array}{c}\text { Rand } \\
\text { Cut-off value }\end{array}$ & Rate \\
\hline $1-6$ & $190-480$ & 1,2062 & $1-6$ & $175-475$ & 1,2225 \\
$6-18$ & $480-1585$ & 1,1045 & $6-18$ & $475-1505$ & 1,101 \\
$18-24$ & $1585-3185$ & 1,1235 & $18-24$ & $1505-3015$ & 1,1227 \\
\hline
\end{tabular}

1980 SURVEY

\begin{tabular}{|r|r|l|r|r|c|}
\hline \multicolumn{2}{|c|}{ Pay structure technique } & \multicolumn{3}{c|}{ Job evaluation technique } \\
\hline Grade No. & $\begin{array}{c}\text { Rand } \\
\text { Cut-off value }\end{array}$ & Rate & Grade No. & $\begin{array}{c}\text { Rand } \\
\text { Cut-off value }\end{array}$ & Rate \\
\hline $1-6$ & $230-565$ & 1,2 & $1-6$ & $225-555$ & 1,2013 \\
$6-17$ & $565-1750$ & 1,1081 & $6-17$ & $555-1625$ & 1,1029 \\
$17-24$ & $1750-3855$ & 1,1197 & $17-24$ & $1625-3515$ & 1,1167 \\
\hline
\end{tabular}


Most important, however, is the fact that the proposed pay structure comparison technique has been consistent in the prediction of the market wage curve over successive survey years. The rand cut-off values and progression rates indicated in Table 2 reveal no significant discrepancies between results obtained from the two techniques used. The significance of the pay structure comparison logic has been supported by this consistency, but is further underlined when taking into consideration the effects of the labour unrest in the mid 70's. Table 3 compares the adjustments to the market wage curve from 1976 to 1977 according to analysis by the two techniques mentioned for job grades one to six.

\section{TABLE 3}

COMPARISON OF ADJUSTMENTS TO MARKET WAGE CURVE VALUES 1976 - 1977

\begin{tabular}{|c|c|c|c|c|c|c|}
\hline \multicolumn{3}{|c|}{ Pay structure technique } \\
\hline $\begin{array}{c}\text { Grade } \\
\text { No. }\end{array}$ & $\begin{array}{c}1976 \text { Value } \\
\text { (Rand) }\end{array}$ & $\begin{array}{c}1977 \text { value } \\
\text { (Rand) }\end{array}$ & $\begin{array}{c}\% \\
\text { Adjust- } \\
\text { ment }\end{array}$ & $\begin{array}{c}1976 \text { value } \\
\text { (Rand) }\end{array}$ & $\begin{array}{c}1977 \text { value } \\
\text { (Rand) }\end{array}$ & $\begin{array}{c}\% \\
\text { Adjust- } \\
\text { ment }\end{array}$ \\
\hline 1 & 180 & 180 & $+4,3$ & 180 & 174 & $-3,3$ \\
2 & 212 & 227 & $+7,1$ & 212 & 213 & $+0,5$ \\
3 & 260 & 274 & $+5,4$ & 260 & 260 & 0 \\
4 & 317 & 330 & $+4,1$ & 317 & 318 & $+0,3$ \\
5 & 390 & 398 & $+2,1$ & 390 & 389 & $-0,3$ \\
6 & 477 & 480 & $+0,6$ & 477 & 475 & $-0,4$ \\
\hline
\end{tabular}

Table 3 reveals that the market wage curve at the lower levels of the grade structure virtually remained static, and in some cases required negative adjustments, for survey data analysed by application of the job evaluation technique. The mean adjustment for grades are to six indicate a negative adjustment of $0,6 \%$. However, this is not the case for the same grades when the pay structure technique of surveying is applied. In this case the mean adjustment is $+3,9 \%$, with positive adjustments for all grades one to six.

The reason for the negative adjustment is attributed to the fact that the job evaluation technique tends to survey actual salaries and thus has reflected the rapid increase in pay rate attributed to the labour unrest. As a result of labour unrest many organisations overreacted by adjusting Black pay rates unrealistically during 1974. Thus actual salaries were greatly increased for Blacks falling at the lower end of the wage curve, and these increases were revealed in salary surveys. However, as these pay increases could not be maintained by most 
organisations, there was a gradual slowdown in pay increases at these same levels over the years 1974 to 1977 , and eventually a negative adjustment to the wage curve was indicated in order to correct unrealistic pay rates at these levels. As revealed by Table 3 this negative adjustment was necessary in order to align such rates with rates payable to other jobs in the labour market, falling at the higher levels of the job hierarchy, and requiring greater skills expertise.

On the other hand, however, the technique of comparing total pay structures, rather than actual salaries, has resulted in market wage curves unaffected by the unrealistic adjustments to actual salaries at the lower levels of the pay structure. This is most desirable as the organisation wishing to adjust its pay structure according to competitive market rates should be able to compare its pay structure with a market wage curve which is not distorted by the subjective "human" element, but which rather reflects objectively determined salary range midpoint values.

\section{CONCLUSION}

This study was undertaken in order to test a technique of surveying market going rates which are unaffected by the subjective human element, while at the same time providing an acceptable solution to the problems associated with separate market wage curves as a result of the wage gap.

Results have indicated that a movement away from use of a subjective technique such as job evaluation to a comparison of pay structures of participating organisations has provided consistently reliable results over successive survey years. Furthermore, comparison of total pay structures has avoided the problems of obtaining actual pay rates which have been affected by distortive market influences.

Finally, most important, this technique has provided a potential solution to the problem of providing a unified non-racial market wage curve in that the surveying of total pay structures in the form of comparable objectively determined salary range midpoints results in a market wage curve which allows for variation in progression rates at different levels of pay structure. These different progression rates correspond with the different levels of the job hierarchy, and thus allow all rates to be incorporated within a single market wage curve. 
Overall then, results suggest the possibility of relying on a technique of surveying which avoids the use of methods requiring subjective application such as a job evaluation, and thus providing an objectively determined market wage curve.

\begin{abstract}
The development and maintenance of an equitable and uniform pay structure is complicated by the existence of the "wage-gap". Choice of a job evaluation plan which does not perpetuate discrimination already found in the market place, and which itself is not discriminatory, has become a topic of debate. Results of this study suggest that it is possible to use a technique for conducting salary surveys which does not rely on subjective techniques such as job evaluation. A comparison of total organisational pay structures, rather than actual salaries, thus provides the basis for a uniform non-racial market wage curve according to which internal pay systems may be competitively structured.
\end{abstract}

\title{
REFERENCES
}

Biesheuvel, S. Outline of a Psychological Job Evaluation System. Johannesburg: National Institute for Personnel Research, 1962.

Biesheuvel, S. Job Evaluation “An outline of the castellion method”. Business Management, 1977, 8(4), 21.

Cogill, C. \& Pearson, M. The wage gap: Job evaluation and Pay structuring. People and Profits, 1978, 6(4), 5-7.

Cortis, L.E. Psychological factors in job evaluation. South African Journal of Psychology, 1972, 2, 55-66.

Etheridge, D.A. Wages, Productivity and Opportunity. Johannesburg: South African Institute of Race Relations, 1973.

Livy, B. Job Evaluation. London: George, Allen and Unwin, 1975.

Orpen, C. Pay and Black Productivity. Management, 1974, 54-61.

Orpen, C. Productivity and Black Workers in South Africa. Cape Town: Juta and Company, 1976.

Paterson, T.T. Job Evaluation. A New Method. London: Pitman Press, 1972.

Snelgar, R.J. The Elements of Job Evaluation in the Development of a Pay Structural Comparison System Guide to Conducting Compensation Surveys. Unpublished Doctoral Dissertation, Rhodes University, 1980. 